\title{
Relating Face to Face. Communicative Practices and Political Decision-Making in a Changing Media Environment
}

\author{
Tanja Pritzlaff-Scheele and Frank Nullmeier
}

\subsection{INTRODUCTION}

In the field of politics, mediatization processes have led to a lot of changes in the ways actors communicate with each other. Following the increased introduction of electronically mediated forms of communication, a vast range of communicative practices that constitute the day-to-day routines of politicians have shifted to the online sphere. But while daily routines - for example exchange of information material-are deeply affected by mediatization processes, practices of decision-making still rely on face-to-face interactions within communicative figurations such as working group meetings, briefings, cabinet meetings or committee meetings. Apparently, within actor constellations that produce

T. Pritzlaff-Scheele $(\bowtie) \cdot$ F. Nullmeier

SOCIUM, University of Bremen, Mary-Somerville-Str. 7, 28359 Bremen, Germany

e-mail: tanja.pritzlaff@uni-bremen.de

F. Nullmeier

e-mail: frank.nullmeier@uni-bremen.de

(C) The Author(s) 2018

A. Hepp et al. (eds.), Communicative Figurations,

Transforming Communications - Studies in Cross-Media Research, https://doi.org/10.1007/978-3-319-65584-0_12 
political decisions, face-to-face communication is still looked upon as the most reliable and effective medium when compared with technically mediated forms of interaction. Therefore, figurations of political decision-making can be identified as an area of strong resistance against changes in the media environment. But why exactly are face-to-face interactions so important in decision-making contexts?

Based on a micro-analysis of face-to-face group experiments and a series of computer-mediated chat experiments, this chapter presents examples of typical sequences of face-to-face interaction that are significant within processes of joint decision-making. The aim of the chapter is to show that these typical sequences or patterns of interaction produce and reproduce specific forms of relatedness within figurations of political decision-making.

The underlying assumption of the analysis can be summed up as follows: the importance of face-to-face interaction leads to the prevalence of specific forms of communicative figurations within the field of politics. This finding can be observed when studying figurations such as working group meetings, briefings, cabinet meetings or committee meetings. While vast areas of day-to-day practices are entangled with electronically mediated forms of communication, face-to-face interaction manifests itself as the core medium when it comes to practices of decision-making. Within the field of politics, therefore, the transformation to deep mediatization takes place in a way that is not homogeneous. Eventually, in times of deep mediatization, changes in the media environment may even lead to an increased importance of face-to-face interaction within the field of politics.

Different from other social domains, politics still relies on 'direct communication', that is, on 'direct conversation with other people' (Hepp 2013: 64) in face-to-face meetings when actual decisions are made. While a vast range of practices and routines within the field of politics have changed owing to the mass distribution of electronic communication devices, the core practice of politics, collective decisionmaking (Easton 1957, 1965; Scharpf 1997), still relies on face-to-face encounters.

At first glance, this finding can be interpreted in line with observations from other social domains as well as with observations from other areas of research in political science: First of all, there are findings in research into other social domains on how issues of confidentiality and trust constitute a challenge to actors involved in technically mediated forms of 
communication (Riegelsberger et al. 2007). Second, the importance of face-to-face interactions is also supported by observations from other areas of decision-making, for example from the private business sector: Especially when it comes to complex decisions that require a significant amount of trust and/or involve decisions on resource allocation and distribution, actors rely on face-to-face meetings. ${ }^{1}$ Finally, various shortcomings of technically mediated forms of decision-making interactions have been identified, for example in the context of studies on online deliberation or protest movements. ${ }^{2}$

But although these studies support the idea that face-to-face interactions are of particular importance to political decision-making, they do not present answers to the core question: Why exactly do face-to-face interactions structure figurations of political decision-making in this way? And, furthermore, why might a changing media environment lead to a point at which they become more important?

Following the concept of communicative figurations, ${ }^{3}$ a promising approach of empirical research that tries to find an adequate answer to these questions is a focus on the construction of relations within actor constellations. If one analyzes the micro-level of political interactions, and especially the micro-level of decision-making interactions, it is possible to identify typical sequences of interaction that constitute important relational structures within figurations of political decision-making.

Furthermore, the micro-analysis of these typical sequences has implications for the meso-analysis of the political domain as a whole. This link becomes apparent if one takes a closer look at the way Norbert Elias introduces the concept of 'figuration':

The network of interdependencies among human beings is what binds them together. Such interdependencies are the nexus of what is here called the figuration, a structure of mutually oriented and dependent people. Since people are more or less dependent on each other first by nature and then through social learning, through education, socialization, and socially generated reciprocal needs, they exist, one might venture to say, only as pluralities, only in figurations. (Elias 2012: 525)

For Elias, the concept of figuration is 'a theoretical conceptualization of interdependent human beings' (Kaspersen and Gabriel 2013: 59). Following this line of thought, human beings are social beings that are 'always embedded in figurations, interdependent webs and networks that 
are always moving, changing, and developing' (Kaspersen and Gabriel 2013: 59). Therefore, Elias focuses on 'relations, processes, and changes in figurations rather than on static structures and states' (Kaspersen and Gabriel 2013: 59).

According to Kaspersen and Gabriel, Elias presents a 'relational perspective' that is 'based on the concept of figuration, which explains that all social life is embedded in interdependent and interweaving social relations' (Kaspersen and Gabriel 2013: 67).

Within this relational perspective, special attention is paid to the embodied, bodily aspects of relational processes. Elias emphasizes the unique emotional and non-verbal capacities of human beings to relate to each other in interaction (Atkinson 2012: 54). He develops a complex, multi-disciplinary theory of embodiment (Atkinson 2012: 55). According to Elias, gestures and facial expressions are 'signals by means of which people communicate involuntarily or with intent the condition of the self-regulation of their emotions to other human beings. The term expression obscures the social, the communicative function of facial and other movements' (Elias 1987: 360).

Therefore, in order to analyze the fundamental differences between face-to-face and technically mediated forms of communicative practices from a relational perspective, it seems promising to take a closer look at communicative practices as speech-body acts (Nullmeier and Pritzlaff 2009: 365) that can be observed in political processes.

In the following, audio-visual data from face-to-face group experiments as well as data from chat-based computer experiments are studied. The analysis of the audio-visual material is based on a micro-ethnographic approach (Streeck and Mehus 2005; LeBaron 2008). Microethnography moves beyond the study of language use in interaction and leads to a holistic study of language use, non-verbal aspects of communication as well as the meaning of bodies and artefacts within the space of interaction. With the help of a micro-ethnographic approach, typical sequences or patterns of face-to-face interactions can be identified in political decision-making contexts. ${ }^{4}$

These sequences of decision-making processes relate the participants of the decision-making interaction to one another. In the following, they are referred to as 'practices of relatedness'. The data from computer-mediated decision-making interactions in a chat environment shows that participants of computer-based decision interactions are more or less unable to perform the same or similar forms of practices or to 
'electronically substitute' in a successful way the practices of relatedness observed in face-to-face interactions.

\subsection{Face-to-Face Interactions in the Field of Politics}

To a large extent, political decision-making takes place in face-to-face interactions within small groups (Sartori 1987: 228). Typical figurations within the field of politics can be identified if one analyzes decisionmaking contexts such as committee meetings, briefings, closed sessions or summits.

But meetings are not only forms of interaction in which resolutions are prepared and adopted and binding agreements are jointly produced. They are also instances of 'We'-creation within certain actor constellations in which the participants of a meeting have to relate to one another in order to produce a joint decision.

Following Peter L. Berger and Thomas Luckmann, it can be assumed that the 'most important experience of others takes place in the faceto-face situation, which is the prototypical case of social interaction. All other cases are derivatives of it' (Berger and Luckmann 1967: 28). If I interact with someone in a face-to-face meeting, a 'continuous reciprocity of expressive acts is simultaneously available to both of us. This means that, in the face-to-face situation, the other's subjectivity is available to me through a maximum of symptoms. [...] Only here is the other's subjectivity emphatically "close". All other forms of relating to the other are, in varying degrees, "remote"' (Berger and Luckmann 1967: 29).

If two or more actors interact with one another in order to arrive at an agreement or joint decision, the functioning of the process seems to improve in cases where multi-layered 'symptoms', as Berger and Luckmann call them, are mutually available. The focus on different 'forms of relating to the other', as outlined by Berger and Luckmann, suggests that there are sequences or patterns of interaction that constitute these different forms of relatedness.

As previous comparisons between face-to-face and technically mediated forms of communication have shown, actors can only to a lesser extent rely on normative resources such as trust in technically mediated episodes of communication (Anderson 2006; Zhou and Zhang 2006). Especially in computer-mediated contexts that rely only on text messages, the 'essential importance of embodied co-presence for the sake of developing and sustaining trust' (Ess 2011: 9) becomes apparent. ${ }^{5}$ 
Furthermore, online deliberation and decision processes are often characterized 'by the noise generated by online asynchronous text based discussion' (Spada et al. 2014: 13). Additionally, findings from studies of decision-making practices in protest movements also suggest that online forms of decision-making produce a lot of disruptive behaviour (Maeckelbergh 2009).

In an ethnographic study on Direct Action (Graeber 2009), David Graeber even comes to the conclusion that 'decision making is the one thing that is almost impossible to do on the Internet' (Graeber 2009: 237). Therefore, protest movements, at least for the most part, still rely on face-to-face interactions when it comes to joint decision-making.

In face-to-face interactions, actors can mutually rely on multi-layered expressive acts through which they evaluate the decision options at hand. Not only practical reasoning in the rational sense, but also emotional and bodily forms of evaluation and judgment are reciprocally available to the actors involved. Or, as Charles Ess points out, in 'the context of embodied co-presence', we are 'forced to confront "the gaze of the morally significant other"' (Ess 2011: 10). Physical, embodied co-presence involves 'the moral gaze of the other' (Ess 2011: 10). It allows us to 'learn to overcome our distrust of one another by "reading" [...] the Other as an embodied being, so to speak, in front of us' (Ess 2011: 24). Therefore, face-to-face communicative practices in general-and practices within figurations of political decision-making in particular-cannot simply be reduced to verbal communication in the sense of mere speech acts, and they cannot be studied in the way one studies written texts. They have to be understood as speech-body acts (Nullmeier and Pritzlaff 2009: 365), as material and embodied expressions that relate actors to one another and manifest themselves not only in time, but also in physical, embodied space. They have to be understood as manifestations and articulations within a dynamic relationship of artefacts, practices and social arrangements (Lievrouw 2014: 45-47).

\subsection{Practices of Relatedness}

Following Joseph Rouse, practices can be defined as 'complex relations of mutual interaction', as patterns of interaction that 'constitute something at issue and at stake in their outcome' (Rouse 2007: 50). Practices are 'complex patterns of mutual responsiveness' (Rouse 2007: 52) that relate individuals within constellations of actors to one another. ${ }^{6}$ 
In the above-cited quote, Berger and Luckmann discuss different 'forms of relating to the other' (Berger and Luckmann 1967: 29). Communicative practices that relate not only participants of an interaction in general, but also their individual positions or individually articulated contributory acts, can be characterized as-to use a term from family sociology - 'practices of relatedness' (Jallinoja and Widmer 2011). Within figurations of political decision-making, these communicative practices produce elements of stability, mutuality and responsiveness. Mutual acts of securing and reassuring are necessary in order to add to the creation of a 'We'-perspective in the ongoing decision-making process and, therefore, are necessary in order to create a situation in which the group as a whole is willing and able to produce a joint decision.

In the context of a micro-analysis of real committee meetings, we identified various patterns or sequences of interaction that can be characterized as practices of relatedness in this sense. The following four examples are micro-elements of interaction that can be observed on a regular basis within figurations of political decision-making, examples being working group meetings, briefings and committee meetings:

- Practices of translation. Practices of translation can be identified as sequences in which participants in political face-to-face interactions try to integrate their different background assumptions and webs of meaning into a unified and harmonized use of concepts. These practices may not ensure that all participants talk about 'the exact same thing' when they talk about something, but since participants start using the same words in order to characterize what they are talking about, these practices promote the successful progression of the decision process.

- Practices of repair. Practices of repair can be identified as microinterventions during sequences of conflict, misunderstanding or disagreement. These practices have the function of putting the respective interaction back on the right track. Practices of repair are usually performed by a third participant who intervenes in cases where the progress of a two-person conversation/dialogue is impeded by a misunderstanding or disagreement. ${ }^{7}$ These practices are often based on non-verbal communication such as gestures and eye contact.

- Practices of renarration. Practices of renarration are sequences in which the participants of a meeting renarrate a proposal that has 
already been made from their own perspective. By telling a slightly different version of the story from their own perspective, actors seem to be able to integrate the proposed decision into their own, differing, background assumptions. In addition, the multiplealthough revised-repetitions of the suggested solution seem to add substance to the idea of a joint solution that the actors as a group can adopt as their decision. Through their non-verbal behaviour, participants signalize the growing coherence of the group, their increasing approval of the story that is told again and again in slight variations.

- Practices of self-authorization. Practices of self-authorization are sequences in which participants reassure each other of their authority as decision-makers. They define and reinforce their position to legitimately make the actual decision at hand. These practices serve to establish, or re-establish, the self-image of the participants as possessing authority and responsibility in the respective case/issue.

These are only four examples of practices of relatedness that we identified in an analysis of actual committee meetings (Nullmeier and Pritzlaff 2009; Pritzlaff and Nullmeier 2011). All of these practices, however, have one thing in common: they rest on a complex, triadic structure of interaction (Lindemann 2006a, 2006b, 2010, 2012) that includes verbal and non-verbal forms of communication and requires- to adapt Ess's above-cited term-a context in which participants can 'read' each other. In order to do this, referring back to Berger and Luckmann, the availability of a 'maximum of symptoms' is of crucial importance to the participants.

Triadic interaction sequences are characterized by relational dynamics that differ from dyadic types of interaction. And although these sequences in which a speaker 'is defining his or her relationship with two other people simultaneously' (Heatherington and Friedlander 2015: 109) have been analyzed mainly in the area of family therapy, it is important to point out that it is 'equally beneficial to capture these types of relational dynamics in other interactional settings involving three or more participants' (Escudero and Rogers 2015: 33). If one wants to analyze these kinds of relational dynamics within figurations of political decision-making, it is extremely important to move beyond the analysis of language use and to include non-verbal, bodily elements of interaction. 


\subsection{EMPIRICAL Findings}

The empirical findings are based on data from two different research projects and a classroom experiment. ${ }^{8}$ In a series of 50 face-to-face group experiments conducted in the first research project, participants were asked to deliberate and decide on three related issues/questions concerning possible regulations in the context of the world financial crisis. ${ }^{9}$ The decision had to be unanimous. Participants were provided with individual role descriptions that led to differing preferences within the group. There was no chairperson assigned to the respective group. Within the given period of time (eight minutes), they were asked to debate and decide on the three issues simultaneously/combined. A decision form with the three questions on it and one ballpoint pen were placed in the middle of the table in order to document the results being reached by the group.

In the context of the second research project, face-to-face as well as chat-based group experiments were conducted. A group consisting of five participants (group A) was asked to decide on a distribution procedure for an extra amount of money that had to be divided between five members of another group consisting of members with different initial financial funding (group B). The group had to choose between three different distribution procedures by creating a rank order among the suggested procedures. The group decision had to be unanimous. In the second phase of the experiment, group B had to decide whether or not to accept the suggested distribution procedure. Again, the decision had to be unanimous. In case they didn't accept the suggested procedure, the participants had to come up with a numerical suggestion on how to distribute the amount. Some of the group A experiments were conducted in a face-to-face environment; the rest of the group A experiments as well as all of the group B experiments were conducted via chat, using the chat function of $\mathrm{z}$-tree (Fischbacher 2007).

The experimental design of the data used shares similarities with political science experiments that are conducted in order to study deliberation processes (Karpowitz and Mendelberg 2011; Setälä and Herne 2014). The idea behind the comparison between the two extreme cases of face-to-face interaction (FTF) and mere text-based, in other words chat-based, computer-mediated communication (CMC), is similar to the research design presented in previous experiments in experimental political science (see for example Frohlich and Oppenheimer 1998). However, 
one thing is to be pointed out when labelling the text-only version an 'extreme case': When comparing FTF interactions to text-based forms of $\mathrm{CMC}$, it seems to be an almost logical consequence to assume that the addition of other modes of communication, such as the combination of video data and text messages in the context of video conferencing systems, has a positive effect in the sense that it enables participants to have a richer form of conversation within a given constellation of actors. One may also assume that the addition of other modes of communication automatically leads to a higher level of cooperation and trust among the participants (Riegelsberger et al. 2007: 64). If this were the case, the conclusion would be that the presented shortcomings of text-based CMC are reduced when visual cues are available, for example through the use of video conferencing systems. It has to be pointed out, however, that there is also evidence to the contrary (see for example Walther 2011:23).

\subsubsection{Empirical Findings from Face-to-Face Experiments}

In the course of the 50 sessions of face-to-face group experiments, the participants performed practices that were very similar to the practices of relatedness identified as important elements within real committee meetings. Owing to the differing preferences and role descriptions within the group that were provided to the participants of the experiments, the participants' attempts to reach a joint decision were rather 'confrontational'. While some of the interactions were dominated by classical practices such as 'coalition building' (Caplow 1968), other sequences of interaction were to a higher degree structured by attempts to address the group as a whole, appealing to the need for unanimity.

In this series of experiments, not only 'repair practices', but also a slightly different practice that furthered the progression of the establishment of common ground and, finally, the production of trust and a joint decision, was performed by various participants. When there was a confrontation between two different opinions/options, individual actors spontaneously took over the function of a chairperson or moderator, summed up the existing different positions within the group in a few sentences and offered a solution. In order to do this, they took a look around, made eye contact with the other group members and used verbal and non-verbal micro-interventions in order to move the decision interaction to the next stage. These 'moderator'-contributory acts served the function of moving the decision interaction to the next stage, 
by hinting at possible relations among the participants. They not only summed up and secured preliminary results, but also contributed to a 'stable' progression of the decision process.

In addition, another practice was performed quite frequently. It turned out to be very important during the analysis of the experiments to take a closer look at the act of writing down the results. In most cases, one of the participants took over the function of filling out the decision form. Although this finding might at first suggest that one participant took over a simple duty, a different reading seems to be more plausible: the respective participant who, at a certain point within the meeting, took the decision form and the pen usually also repeated and summed up the results (renarration) and stressed the importance of an agreement being reached by the group as a whole. This 'decision closing'-practicewith a focus on actually reaching a result-can be described as based on one participant's 'reading' of the group as a whole. The contributory acts performed by the participant who took over the function of the chairperson are similar to contributory acts that are usually performed by the chairperson in real committee meetings. In order to 'read' the group as a whole, the respective participant heavily relied on non-verbal cues. By performing this type of practice, the participants helped to establish a stable relational structure which served as the basis for the joint decision.

Similar findings were identified during the analysis of the audio-visual recordings of face-to-face group experiments conducted in the context of the FOR 2104 research project on needs-based distribution procedures.

\subsubsection{Empirical Findings from Chat Experiments}

In the context of the above-mentioned classroom experiment, computer-mediated chat experiments were conducted in an experimental economics laboratory, ${ }^{10}$ to test the differences between face-to-face and computer-mediated decision interactions (hereafter referred to as classroom experiment). Similar to the face-to-face group experiments, participants were asked to decide on three related issues/questions. During the experiment, participants were able to deliberate with the members of their group using CMC, that is, an integrated chat function. ${ }^{11}$

In the course of the chat communication, participants tried to perform certain contributory acts in order to electronically substitute relational practices of translation and repair. But these attempts to relate to one another didn't work - not because of the time delay in written 
communication, but also because participants weren't able to create triadic communication constellations. In face-to-face interactions, this is done using non-verbal forms of communication, such as eye contact and non-verbal utterances. To substitute the lack of mutual availability of multi-layered 'symptoms', in other words the lack of those elements that create an emphatically 'close' subjectivity in the sense of Berger and Luckmann, the participants of the classroom experiment used 'emoticons' during chats $(\cdot,+)$ ) or abbreviations and acronyms such as LOL (for 'laughing out loud').

Computer-mediated communication took longer, since all acts of signalizing acceptance had to be verbalized and put into written form. And communication didn't go too smoothly-in part because it was perceived as rather anonymous by the participants, but also because 'microinterventions', in the sense of practices of relatedness, weren't possible in this setting. And although the participants of the classroom experiment knew each other, Table 12.1 shows that trust was still an issue in this CMC environment.

Obviously, although the remark concerning participant three being a spy is ironic, the participants find it difficult to build trust in this environment, ${ }^{13}$ and joint decision-making doesn't proceed very smoothly.

In the context of the above-mentioned FOR 2104 research project on needs-based distribution procedures, another series of experiments was conducted using the chat function of $z$-tree. The section presented in Table 12.2 is an excerpt from these experiments. In this particular chat-based experiment, participants had to agree on a ranking between three different distribution procedures (Majority Decision by the concerned persons themselves $[\mathrm{MAJ}]$, Weaker First [WF] and Effort $[\mathrm{EFF}])$. As the example shows, they struggle with the task to verify that each of them actually agrees with a suggested ranking (MAJ, EFF, WF). They repeat the proposal again and again, and try to figure out if all of the five members of the group actually understood the suggestion and are willing to join the group in a unanimous decision.

In the context of the FOR 2104 chat experiments, 36 groups with five participants each were assigned to the group $B$ research design where a group had to discuss whether or not to accept a distribution procedure imposed on them by group A. ${ }^{15}$ In case they did not accept the suggested distribution procedure, they had the opportunity to agree on 
Table 12.1 Chat protocol from classroom experiment

\begin{tabular}{|c|c|c|}
\hline$P^{12}$ & Original text & Translation \\
\hline 6 & $\begin{array}{l}\text { Frage 2: hat jemand Einwand gegen } \\
\text { "sinnvoll"? }\end{array}$ & $\begin{array}{l}\text { Question 2: does anyone object to } \\
\text { "useful"? }\end{array}$ \\
\hline 5 & ok & $\mathrm{OK}$ \\
\hline 3 & $\begin{array}{l}\text { also aufklärung weiter verstärken oder } \\
\text { wie? }\end{array}$ & $\begin{array}{l}\text { Thus, keeping people informed more or } \\
\text { what? }\end{array}$ \\
\hline 1 & ja & Yes \\
\hline 4 & $\mathrm{Ja}$ & Yes \\
\hline 2 & ja & Yes \\
\hline 3 & nö! hab ich nichts gegen & Nope! I don't have anything against that \\
\hline 1 & gut also angenommen & Fine, accepted then \\
\hline 6 & was ja? Einwand? & What's the yes for? Objection? \\
\hline 1 & nummer zwei: sinnvoll & Number 2: useful \\
\hline 6 & oder einverstanden? & Or accepted? \\
\hline 2 & ja & Yes \\
\hline 3 & wie jetzt? & Meaning what? \\
\hline 2 & keiner sagt was dagegen oder? & Nobody says anything against this, right? \\
\hline 4 & einverstnden sinnvoll, was ist mit Frage 3 & Accepted useful, what about question 3 \\
\hline 3 & was denn nu? & What now? \\
\hline 2 & ja sinnvoll verdammt & Yes useful damn it \\
\hline 6 & okay, also frage 3 & Okay, so question 3 \\
\hline 3 & bin ich gegen! & I am against that! \\
\hline 1 & du wurdest aber überstimmt & But you were overruled \\
\hline 2 & keine maßnahmen & No measures \\
\hline 6 & keine massnahmen finde ich auch & I agree, no measures \\
\hline 3 & hä wo jetzt? & Huh? Where exactly? \\
\hline 6 & bei 3 & At 3 \\
\hline 1 & keine maßnahmen & No measures \\
\hline 3 & genau keine maßnahmen! & Exactly, no measures! \\
\hline 3 & sag ich doch! & That's what I was saying! \\
\hline 5 & warum?? & Why?? \\
\hline 1 & $\begin{array}{l}\text { ich glaub, dass nummer drei ein spion ist, } \\
\text { der alle verunsichern will;-) }\end{array}$ & $\begin{array}{l}\text { I believe that number three is a spy who } \\
\text { wants to unsettle us all;-) }\end{array}$ \\
\hline
\end{tabular}

an alternative distribution of 20 experimental tokens (which equals 10 euros). In the course of the 36 sessions, three groups came up with the idea to hand over all of the 20 tokens to one participant and to split the profit after the experiment had ended. In all of the three cases, this option was discussed in the chat environment, but in all of the three cases the participants weren't able to agree on the way to proceed. They all agreed that by 'cheating' on the experimental task in this way 
Table 12.2 Chat protocol from FOR 2104 pre-test. ${ }^{14}$ (Hamburg ID 2/group 2) structure: group chat; decision rule: unanimity

\begin{tabular}{|c|c|c|}
\hline Player no. & Chat & Translation \\
\hline 4 & $\begin{array}{l}\text { jetzt schreibt jeder player seine } \\
\text { vorschlagnummer, dann sehen wir } \\
\text { mehr in der Mehrheit ist }\end{array}$ & $\begin{array}{l}\text { Now, each player writes down his } \\
\text { proposed numbers, then we'll see } \\
\text { who has the majority }\end{array}$ \\
\hline 5 & ZUSAMMENFASSUNG BITTE & SUMMARY PLEASE \\
\hline 3 & aber hier ist es ja was anderes & But here it's something different \\
\hline 3 & geringste ausstattu8ng & Least endowment \\
\hline 3 & wenn wir & If we \\
\hline 3 & sagen das side am meisten kriegen & Say that they receive the most \\
\hline 1 & SG / MEHR / LEI & $\mathrm{WF} / \mathrm{MAJ} / \mathrm{EFF}$ \\
\hline 3 & $\begin{array}{l}\text { ist es unfair den anderen die sich anst- } \\
\text { trengen eggenßüber }\end{array}$ & $\begin{array}{l}\text { It is unfair with regard to those who } \\
\text { try hard }\end{array}$ \\
\hline 3 & $\begin{array}{l}\text { ausserdem würde doch ehrlioch jeder } \\
\text { am liebsten nix tuhen }\end{array}$ & $\begin{array}{l}\text { Furthermore, to be honest, everyone } \\
\text { would prefer to do nothing }\end{array}$ \\
\hline 3 & und kohle kassieren & And just collect the cash \\
\hline 5 & player 2, dein Vorschlag bitte & Player 2, your proposal please \\
\hline 4 & $\begin{array}{l}\text { player 1, kannst du dich nicht einfach } \\
\text { bitte der Mehrheit anschliessen? }\end{array}$ & $\begin{array}{l}\text { Player } 1 \text {, could you please just join } \\
\text { the majority? }\end{array}$ \\
\hline 1 & die versuchen wir ja grad rauszufinden & We just try to figure out what that is \\
\hline 2 & $\begin{array}{l}\text { Jeder einmal seinen bevorzugten } \\
\text { Vorschlag, dann haben wir Übersicht. }\end{array}$ & $\begin{array}{l}\text { Everyone: your preferred proposal, so } \\
\text { we can get an overview }\end{array}$ \\
\hline 3 & haben wir doch schon & We already have it \\
\hline 3 & das ist demokratie ;) & That's democracy ;) \\
\hline 1 & $\begin{array}{l}\text { jeder bitte nochmal genaue Rangfolge } \\
\text { aufschreiben }\end{array}$ & $\begin{array}{l}\text { Everyone please: write down your } \\
\text { exact order of preference }\end{array}$ \\
\hline 5 & $\begin{array}{l}\text { player } 1 \text { war schon dran, nun player } \\
2 \text { bitte }\end{array}$ & $\begin{array}{l}\text { Player } 1 \text { already had his turn, now } \\
\text { player } 2 \text { please }\end{array}$ \\
\hline 3 & haben nur noch 170 sek & We only have $170 \mathrm{sec}$ \\
\hline 2 & Mehr/SG/Lei & $\mathrm{Maj} / \mathrm{WF} / \mathrm{Eff}$ \\
\hline 3 & -. & $\ldots$ \\
\hline 5 & player 3 & Player 3 \\
\hline 3 & $\begin{array}{l}\text { warum solen die die leistunge } \\
\text { rbrignen schlechter egstellt werden als } \\
\text { die die eh nix tunß }\end{array}$ & $\begin{array}{l}\text { Why should those who perform } \\
\text { well be worse off than those who do } \\
\text { nothing }\end{array}$ \\
\hline 3 & vorswchlag: & Suggestion: \\
\hline 4 & Mehr/SG/Lei & $\mathrm{Maj} / \mathrm{WF} / \mathrm{EFF}$ \\
\hline 3 & MEHR/LEI/SG & $\mathrm{MAJ} / \mathrm{EFF} / \mathrm{WF}$ \\
\hline 4 & fuck sorry stimme $3 \mathrm{zu!}$ & Fuck sorry I agree with 3 ! \\
\hline 3 & hahahaah dachet schon :D & Hahahaah I thought so :D \\
\hline 4 & MEHR LEI SG & MAJ EFF WF \\
\hline 3 & jo & Yeah \\
\hline 5 & mher lei sg & maj eff wf \\
\hline
\end{tabular}


Table 12.2 (continued)

\begin{tabular}{|c|c|c|}
\hline Player no. & Chat & Translation \\
\hline 1 & also alle für MEHR / SG / LEI ???? & $\begin{array}{l}\text { Now, everyone for MAJ/WF/ } \\
\text { EFF??? }\end{array}$ \\
\hline 4 & JAAAAAA & YEAHHH \\
\hline \multicolumn{3}{|r|}{ 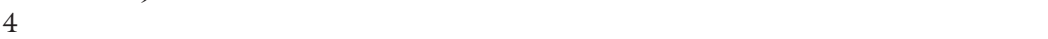 } \\
\hline 1 & außer mir ... menno & Except me ... gosh \\
\hline 3 & what? & What? \\
\hline 5 & mehr sg lei & maj wf eff \\
\hline 3 & $\begin{array}{l}\text { dachet mehrheit lesitungs } \\
\text { chlechtgestellt }\end{array}$ & I thought majority effort weaker first \\
\hline \multicolumn{3}{|c|}{ 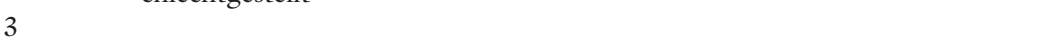 } \\
\hline 4 & 3 sind für MEHR LEI SG & 3 are in favour of MAJ EFF WF \\
\hline 3 & jo & Yep \\
\hline 3 & oki & $\mathrm{OK}$ \\
\hline 5 & mehr lei sg, ok & maj eff wf, okay \\
\hline 1 & okay MEHR / LEI / SG.... & $\mathrm{OK}, \mathrm{MAJ} / \mathrm{EFF} / \mathrm{WF}$ \\
\hline 4 & $\begin{array}{l}\text { PLAYER } 5 \text { und } 1 \text { schliesst ihr euch } \\
\text { an? }\end{array}$ & PLAYER 5 and 1 do you join us? \\
\hline 5 & ja & Yes \\
\hline 4 & juhuu & Yay \\
\hline 3 & player 2 meinst du ;) & You mean player 2 ;) \\
\hline 1 & immer doch ...;) & Still $\ldots ;)$ \\
\hline 2 & $\mathrm{OK}$ & $\mathrm{OK}$ \\
\hline 3 & leute noch 25 sek :S & Folks only $25 \mathrm{sec}: S$ \\
\hline 5 & mehr lei sg & maj eff wf \\
\hline 1 & MEHR LEI SG & MAJ EFF WF \\
\hline 4 & geiloooo & Awesome \\
\hline
\end{tabular}

they would earn more money. But they were not sure whether or not they could trust the one person who would leave the lab with the total amount of money. Since the participants of the FOR 2104 experiments did not know each other, the creation of trust was even more difficult. In Table 12.3, player 5 identifies herself as 'the girl with the blue shirt'. But even after that, the other participants are not able to reach a decision that would end up by handing over all the money to player 5 and splitting the profit after the experiment ('We could meet on the staircase on first floor'). 
Table 12.3 Chat protocol from FOR 2104 experiments (Hamburg group no. 16)

$P$ Original Text Translation

1 also wenn wir player 5 alles geben haben wir einen gewinn von 51,5 , also 25,5 Euro, sind ca 6 euro für jeden

1 wenn wir das machen wir ihr meint haben wir einen gewinn von 42,5 token

5 Ja super, Player 1 und 2, ich hoffe ihr seit damit einverstanden?

1 also 21 euro und die unfair verteilt

1 aber zur not bin ich damit einverstanden :D

3 ok, wer stimmt für $11 / 6 / 3$ ?

1 11,6,3,0,0?

5 moment

3 genau

56 euro für jeden

1 sehe ich nicht als sinnvoll an aber na gut $=\mathrm{D}$

5 pro diese runde?

1 das risiko ist halt dass player 5 nicht solidarisch wäre und abhaut

5 Ich bin solidarisch!!!!!!

4 sont wie option eins und wir vertrauen auf player 5 ;)

5

$1: \mathrm{D}$

5 jaaaa

1 mir egal müsst ihr wissen

5 also ich bin player 5 und bin ein mädel mit blauem Shirt!!!

1 player 5 gibt uns einfach 6 euro nachm spiel

4 :D na dann

1 können uns ja im ersten stock im treppenhaus treffen

4 ok

3 ich wähle $11 / 6 / 3 / 0 / 0$

5 moment

1 da sind nicht so viele leute

4 ja besser

5 oh
Now, if we hand over everything to player 5 , we'll have a profit of 51,5 , that is 25,5 Euros, and this is approx. 6 Euros per person

If we do it the way you suggested we'll have a profit of 42,5 token

Yes, awesome, player 1 and 2, I hope you agree with that?

So, 21 Euros distributed unfairly

But if necessary I agree with that :D

OK, who votes for $11 / 6 / 3$ ?

$11,6,3,0,0$ ?

Just a moment

exactly

6 Euros each

I don't think this is reasonable but well, all right $=\mathrm{D}$

Per round?

There is a risk involved that player 5 doesn't show solidarity and disappears I show solidarity!!!!!!

Otherwise like option one and we trust player 5 ;)

\section{:D}

\section{Yeeeaaas}

I don't care, I leave it to you

Now, I am player 5 and I am a girl in a blue shirt!!!

Player 5 will simply hand over 6 Euros to us after the game

:D OK ...

We could meet on the staircase on first floor

OK

I choose $11 / 6 / 3 / 0 / 0$

Just a moment

Since there are not that many people around

Yes, that's better

$\mathrm{Oh}$ 
Table 12.3 (continued)

\begin{tabular}{|c|c|c|}
\hline$P$ & Original Text & Translation \\
\hline 5 & ich check das gerade nicht & I don't understand \\
\hline 5 & 6 euro pro runde oder was? & 6 Euros per round or what? \\
\hline 2 & $\begin{array}{l}\text { leute was nun? draußen treffen und ver- } \\
\text { teilen oder } 1163 \text { ? }\end{array}$ & $\begin{array}{l}\text { Folks, what now? Meet outside or distrib- } \\
\text { ute } 1163 \text { ? }\end{array}$ \\
\hline 3 & 1163 & 1163 \\
\hline 5 & ja dann lass also bei der verteilung 1163 & Yes, let's stick to the distribution 1163 \\
\hline 1 & $\begin{array}{l}\text { ja soweit ich das verstanden habe } 6 \text { pro } \\
\text { runde }\end{array}$ & $\begin{array}{l}\text { Yes, as far as I understood it's } 6 \text { Euros per } \\
\text { round }\end{array}$ \\
\hline 5 & bleiben.... & After all $\ldots$ \\
\hline 1 & ja ok $=\mathrm{D}$ & Yes $\mathrm{OK}=\mathrm{D}$ \\
\hline 3 & ich stimme jetzt ab & I'll vote now \\
\hline 5 & also 6 runden ... moment & Well, 6 rounds ... just a moment \\
\hline 1 & $\begin{array}{l}\text { ich weiß nicht wie oft die verteilung statt } \\
\text { findet }\end{array}$ & $\begin{array}{l}\text { I don't know how often the distribution } \\
\text { will take place }\end{array}$ \\
\hline 5 & ja... & Yes... \\
\hline 1 & ok also $11,6,3$ ? müssen uns entscheiden & $\begin{array}{l}\text { OK, } 11,6,3 \text { then? We have to reach a } \\
\text { decision }\end{array}$ \\
\hline 5 & ja & Yes \\
\hline
\end{tabular}

The examples seem to suggest that participants of text-based computer-mediated decision interactions are not able to create practices of relatedness-practices that rest on triadic constellations of interactions, non-verbal aspects of communication and micro-scale acts of reciprocal reassurance. And although they are able to reach a joint decision, the dominance of - rather unstable - dyadic constellations even leads to a point where two participants engaged in a dialogue are not sure whether the other participants are still present.

Obviously, the above-described practices of relatedness-practices that exhibit a complex, triadic, synchronous structure-cannot be performed or substituted in a chat environment. And although there are more sophisticated platforms for online deliberation available, difficulties remain (see for example Klein 2011; Spada et al. 2014). ${ }^{16}$ Furthermore, empirical evidence from various areas of research in political science suggests that David Graeber might be right when he concludes that 'decision making is the one thing that is almost impossible to do on the Internet' (Graeber 2009: 237)—or while using other forms of technically mediated communication. 
The presented findings suggest that practices of relatedness play a central role at the micro-level of decision-making interactions. And these findings are not only important for the study of specific figurations of political decision-making, but also for the meso-level of the political domain and the macro-level of society as a whole. It might also be assumed that the more complex-and the more important-joint decisions are, the more important it seems to be for the actors involved to meet each other face to face. Questions of resource distribution or redistribution, for example, require a level of relatedness within figurations of political decision-making that is difficult to create in a CMC environment.

\subsection{Conclusion}

The aim of this chapter has been to introduce a possible answer to the question why decision interactions within figurations of political decision-making still rely on face-to-face interactions. Certain features inherent in face-to-face, embodied communicative practices, performed under conditions of physical co-presence, seem to promote the production of trust and reciprocity within actor constellations. Among other things, sequences referred to as practices of relatedness ensure that the decision process runs smoothly. In cases of disagreements or misunderstandings, practices of repair can put the process back on the right track. But these are practices that have a very complex, synchronous structure. And they rely on verbal as well as non-verbal elements of communicative practices. Therefore, it seems almost impossible to perform similar practices in computer-mediated communication. Practices of relatedness contribute to the success of problem-solving interactions, for example in cases in which political decisions are made concerning resource distributions. Practices of relatedness have a triadic, synchronous structure, while chat environments seem to be restricted to dyadic-and often a-synchronous-forms of interaction. Therefore, the empirical results suggest that these micro-scale acts of correction, translation and repair are found exclusively in face-to-face interactions, where, to cite Berger and Luckmann again, 'the other's subjectivity is available to me through a maximum of symptoms' (Berger and Luckmann 1967: 29). These micro-level practices structure actor constellations within the field of politics in a way that has important implications for the study of communicative figurations and transforming communications in politics in 
general. While vast areas of day-to-day political practices and routines are backed up or substituted by electronically mediated forms of communication, face-to-face interaction manifests itself as the core medium of political decision-making. In a time of 'deep mediatization', figurations of political decision-making are a striking example for the fact that we are not dealing with a linear and homogeneous process. These figurations hint at the possibility of communicative practices and actor constellations that resist mediatization.

With regard to future studies of communicative figurations in the field of politics, other important aspects can be analyzed on the basis of the presented findings: In politics, at least for the most part, face-to-face meetings can be characterized as exclusive venues that usually involve limited access and restrictions of participation. If face-to-face meetings persist, and even gain importance within the political process, this increased importance raises issues of power relations, inequalities and exclusion. Even today, questions of who gets access to which face-to-face meeting and who has the power to decide about access within actor constellations already structure figurations of political decision-making in a crucial way. Therefore, the increasing significance and focal position of face-to-face interactions within the field of politics present an ongoing challenge to future studies of mediatization processes in politics and of typical figurations of political decision-making.

\section{Notes}

1. Although one would assume, as Judy Wajcman outlines, that the 'spatialtemporal practices' of highly mobile professionals have changed dramatically through the widespread use of technically mediated communication, it turned out that 'their time became dominated by a concern to connect in time and space because they considered face-to-face meetings to be the paramount means of communicating in organizations' (Wajcman 2015: 20; see also Brown and O'Hara 2003).

2. See, for example, Graeber 2009; Maeckelbergh 2009; Hartz-Karp and Sullivan 2014.

3. According to Hepp and Hasebrink, communicative figurations are 'patterns of processes of communicative interweaving that exist across various media and have a thematic framing that orients communicative action' (Hepp and Hasebrink 2014: 258).

4. Like other forms of qualitative data analysis, micro-ethnography has to carefully design and document procedures for coding to make 
replication possible' (Neuman 1997: 274). Researchers have to 'take various steps to ensure this replicability' (Rose 2012: 96), including tests of coder reliability. The data coding and data organization process, including written transcripts of audio-visual material (Pink 2007: 136), have to be documented by the research team.

5. As Ess further outlines, this may change in cases where modalities other than text messages are available: 'In light of the way in which disembodiment online is a primary obstacle to our establishing and fostering trust with one another in online venues and environments, the return of the body-e.g., as more directly represented via video and audio in the various venues and modalities made possible by Web 2.0-thereby reduces online disembodiment and at least increases the possibilities of our re-presenting our bodies (including facial gestures and other components of nonverbal communication) in ways that may help establish and foster trust' (Ess 2011: 24). For a discussion on changes when it comes to 'issues around co-presence and embodiment' (Cumiskey and Hjorth 2013: 2) with regard to smartphone use and other mobile forms of mediated communication, see Cumiskey and Hjorth 2013.

6. For a detailed theoretical discussion on the concept of practice, see Pritzlaff-Scheele 2015.

7. Practices of repair are also discussed in Conversation Analysis (Schegloff et al. 1977; Goodwin 2003, 2006; Arminen 2005; Nielsen 2009). Schegloff refers to practices of repair as 'main guarantors of intersubjectivity and common ground in interaction' (Schegloff 2006: 79).

8 . In the context of a research project funded by the NOWETAS foundation, 50 face-to-face group experiments with a total of 210 participants were conducted, as well as a series of chat experiments. The second project is part of the DFG Research Unit 'Needs-Based Distribution and Distribution Procedures' (FOR 2104).

9. The 'storyline' of the experimental design was that the participants were members of an advisory board that had to decide on the German position concerning the regulation of financial markets.

10. An experimental economics laboratory usually consists of a network of 20 to 30 connected subject stations (computers) and a monitor station for the researcher. The participants/experimental subjects are located in individual cabins separated by walls or shields in order to ensure anonymity. An experimental economics laboratory provides a controlled environment to observe individual and collective decision-making processes.

11. The experiments were conducted at the Carl-von-Ossietzky-Universität Oldenburg on 24 April 2008. The experiments were based on the software z-tree (Fischbacher 2007).

12. Number of the respective participant. 
13. Again, it has to be pointed out that different from the experimental setting of the FOR 2104 chat experiments presented below, the participants of the classroom experiment knew each other-the experiment took place in the middle of a graduate class on experimental political science. Although they didn't know during the experiment who had what number-and so didn't know who number three was-they knew that number three had to be one of their fellow graduate students.

14. The pre-tests were conducted in the WISO Research Lab at the University of Hamburg on 17 September 2015.

15. The experiments were conducted in the WISO Research Lab at the University of Hamburg on 11 and 12 July 2016.

16. Hartz-Karp and Sullivan suggest using an integrated system based on 'synchronous video, voice and chat'-but according to them, in order to create a functioning 'public square' for deliberation, this integrated system has to be complemented by face-to-face deliberation (Hartz-Karp and Sullivan 2014: 4).

\section{REFERENCES}

Anderson, Anne H. 2006. Achieving understanding in face-to-face and videomediated multiparty interactions. Discourse Processes 41 (3): 251-287.

Arminen, Ilkka. 2005. Institutional interaction: Studies of talk at work. Aldershot and Burlington, VT: Ashgate.

Atkinson, Michael. 2012. Norbert Elias and the body. In Routledge handbook of body studies, ed. Bryan S. Turner, 49-61. Abingdon, Oxford: Routledge.

Berger, Peter L., and Thomas Luckmann. 1967. The social construction of reality. A treatise in the sociology of knowledge. New York: Anchor Books.

Brown, Barry, and Kenton O'Hara. 2003. Place as a practical concern of mobile workers. Environment and Planning A 35 (9): 1565-1587.

Caplow, Theodore. 1968. Two against one. Coalitions in triads. Englewood Cliffs, NJ: Prentice-Hall.

Cumiskey, Kathleen M., and Larissa Hjorth. 2013. Between the seams. Mobile media practice, presence and politics. In Mobile media practices, presence and politics. The challenge of being seamlessly mobile, ed. Kathleen M. Cumiskey and Larissa Hjorth, 1-11. New York and Abingdon, Oxford: Routledge.

Easton, David. 1957. An approach to the analysis of political systems. World Politics 9 (3): 383-400.

Easton, David. 1965. A systems analysis of political life. New York: Wiley.

Elias, Norbert. 1987. On human beings and their emotions: A process-sociological essay. Theory, Culture of Society 4 (2): 339-361.

Elias, Norbert. 2012. On the process of civilisation. Collected works, vol. 3. Dublin: UCD Press. 
Escudero, Valentín, and L. Edna Rogers. 2015 [2004]. Observing relational communication. In Relational communication. An interactional perspective to the study of process and form, ed. Valentín Escudero and L. Edna Rogers, 23-49. New York and London: Psychology Press.

Ess, Charles. 2011. Self, community, and ethics in digital mediatized worlds. In Trust and virtual worlds. Contemporary perspectives, ed. Charles Ess and May Thorseth, 3-30. New York and Washington DC: Peter Lang.

Fischbacher, Urs. 2007. z-Tree: Zurich toolbox for readymade economic experiments. Experimental Economics 10 (2): 171-178.

Frohlich, Norman, and Joe Oppenheimer. 1998. Some consequences of e-mail vs. face-to-face communication in experiment. Journal of Economic Behavior \& Organization 35 (3): 389-403.

Goodwin, Charles. 2003. Conversational frameworks for the accomplishment of meaning in aphasia. In Conversation and brain damage, ed. Charles Goodwin, 90-116. Oxford: Oxford University Press.

Goodwin, Charles. 2006. Human sociality as mutual orientation in a rich interactive environment: Multimodal utterances and pointing in aphasia. In Roots of buman sociality, ed. Nicholas J. Enfield, and Stephen C. Levinson, 96-125. Oxford and New York: Berg Press.

Graeber, David. 2009. Direct action. An ethnography. Oakland, CA and Edinburgh: AK Press.

Hartz-Karp, Janette, and Brian Sullivan. 2014. The unfulfilled promise of online deliberation. Journal of Public Deliberation 10 (1): 1-5.

Heatherington, Laurie, and Myrna L. Friedlander. 2015 [2004]. From dyads to triads, and beyond: Relational control in individual and family therapy. In Relational communication. An interactional perspective to the study of process and form, ed. Valentín Escudero and L. Edna Rogers, 103-129. New York and London: Psychology Press.

Hepp, Andreas. 2013. Cultures of mediatization. Cambridge and Malden, MA: Polity Press.

Hepp, Andreas, and Uwe Hasebrink. 2014. Human interaction and communicative figurations. The transformation of mediatized cultures and societies. In Mediatization of communication, ed. Knut Lundby, 249-272. Berlin and New York: de Gruyter.

Jallinoja, Riitta, and Eric Widmer. 2011. Introduction. In Families and kinship in contemporary Europe: Rules and practices of relatedness, ed. Riitta Jallinoja, and Eric Widmer, 3-12. Basingstoke: Palgrave.

Karpowitz, Christopher, and Tali Mendelberg. 2011. An experimental approach to citizen deliberation. In Cambridge handbook of experimental political science, ed. James N. Druckman, Donald P. Green, James H. Kuklinski, and Arthur Lupia, 258-272. Cambridge, MA and New York: Cambridge University Press. 
Kaspersen, Lars B., and Norman Gabriel. 2013. Survival units as the point of departure for a relational sociology. In Applying relational sociology: Relations, networks, and society, ed. François Dépelteau, and Christopher Powell, 51-82. New York: Palgrave.

Klein, Mark. 2011. How to harvest collective wisdom on complex problems: An introduction to the MIT Deliberatorium. MIT Center for Collective Intelligence Working Paper.

LeBaron, Curtis D. 2008. Microethnography. In The international encyclopedia of communication, Vol. 7: Media corporations, forms of-objectivity in reporting, ed. Wolfgang Donsbach, 3120-3124. Oxford and Malden, MA: Wiley-Blackwell.

Lievrouw, Leah A. 2014. Materiality and media in communication and technology studies: An unfinished project. In Media technologies. Essays on communication, materiality, and society, ed. Tarleton Gillespie, Pablo J. Boczkowski, and Kirsten A. Foot, 21-51. Cambridge and London: The MIT Press.

Lindemann, Gesa. 2006a. Die dritte Person-das konstitutive Minimum der Sozialtheorie. In Philosophische Anthropologie im 21. Jahrhundert, ed. HansPeter Krüger and Gesa Lindemann, 125-145. Berlin: Akademie Verlag.

Lindemann, Gesa. 2006b. Die Emergenzfunktion und die konstitutive Funktion des Dritten. Perspektiven einer kritisch-systematischen Theorieentwicklung. Zeitschrift für Soziologie 35 (2): 82-101.

Lindemann, Gesa. 2010. The lived body from the perspective of the shared world (Mitwelt). Journal of Speculative Philosophy 24 (3): 275-291.

Lindemann, Gesa. 2012. Die Kontingenz der Grenzen des Sozialen und die Notwendigkeit eines triadischen Kommunikationsbegriffs. Berliner Journal für Soziologie 22 (3): 317-340.

Maeckelbergh, Marianne. 2009. The will of the many. How the Alter-globalization Movement is changing the face of democracy. London and New York: Pluto Press.

Neuman, W.Lawrence. 1997. Social research methods: Qualitative and quantitative approaches. Boston, MA: Allyn \& Bacon.

Nielsen, Mie F. 2009. Interpretative management in business meetings. Understanding managers' interactional strategies through conversation analysis. Journal of Business Communication 46 (1): 23-56.

Nullmeier, Frank, and Tanja Pritzlaff. 2009. The implicit normativity of political practices. Analyzing the dynamics and power relations of committee decisionmaking. Critical Policy Studies 3 (3-4): 357-374.

Pink, Sarah. 2007. Doing visual ethnography, 2nd ed. Los Angeles and London: Sage.

Pritzlaff-Scheele, Tanja. 2015. Prefigurative politics. The normativity of political practice. Unpublished Habilitation Manuscript, University of Bremen. 
Pritzlaff, Tanja, and Frank Nullmeier. 2011. Capturing practice. Evidence \& Policy 7 (2): 137-154.

Riegelsberger, Jens, M. Angela Sasse, and John D. McCarthy. 2007. Trust in mediated interactions. In The Oxford handbook of internet psychology, ed. Adam N. Joinson, Katelyn Y.A. McKenna, Tom Postmes, and Ulf-Dietrich Reips, 53-69. Oxford and New York: Oxford University Press.

Rose, Gillian. 2012. Visual methodologies. An introduction to researching with visual materials, 3rd ed. Los Angeles, CA and London: Sage.

Rouse, Joseph. 2007. Social practices and normativity. Philosophy of the Social Sciences 37 (1): 46-56.

Sartori, Giovanni. 1987. The theory of democracy revisited. Part I: The contemporary debate. Chatham, NJ: Chatham House.

Scharpf, Fritz W. 1997. Games real actors play: Actor-centered institutionalism in policy research. Boulder, CO: Westview Press.

Schegloff, Emanuel A. 2006. Interaction: The infrastructure for social institutions, the natural ecological niche for language, and the arena in which culture is enacted. In Roots of human sociality, ed. Nicholas J. Enfield, and Stephen C. Levinson, 70-96. Oxford and New York: Berg Press.

Schegloff, Emanuel A., Gail Jefferson, and Harvey Sacks. 1977. The preference for self-correction in the organization of repair in conversation. Language 53 (2): 361-382.

Setälä, Maija, and Kaisa Herne. 2014. Normative theory and experimental research in the study of deliberative mini-publics. In Deliberative mini-publics. Involving citizens in the democratic process, ed. Kimmo Grönlund, André Bächtiger, and Maija Setälä, 59-75. Colchester: ECPR Press.

Spada, Paolo, Mark Klein, Raffaele Calabretta, Luca Iandoli, and Ivana Quinto. 2014. A first step towards scaling-up deliberation: Optimizing large group e-deliberation using argument maps. Paper presented at the American Political Science Association (APSA). 110th Annual Meeting, Politics after the Digital Revolution. Washington DC, 28-31. 08. 2014.

Streeck, Jürgen, and Siri Mehus. 2005. Microethnography. The study of practices. In Handbook of language and social interaction, ed. Kristine L. Fitch and Robert E. Sanders, 381-404. Mahwah, NJ and London: Lawrence Erlbaum.

Wajcman, Judy. 2015. Pressed for time. The acceleration of life in digital capitalism. Chicago and London: University of Chicago Press.

Walther, Joseph B. 2011. Visual cues in computer-mediated communication: Sometimes less is more. In Face-to-face communication over the internet. Emotions in a web of culture, language and technology, ed. Arvid Kappas and Nicole C. Krämer, 17-38. Cambridge and New York: Cambridge University Press.

Zhou, Lina, and Donsong Zhang. 2006. A comparison of deception behavior in dyad and triadic group decision making in synchronous computer-mediated communication. Small Group Research 37 (2): 140-164. 
Open Access This chapter is licensed under the terms of the Creative Commons Attribution 4.0 International License (http://creativecommons.org/licenses/ by $/ 4.0 /$ ), which permits use, sharing, adaptation, distribution and reproduction in any medium or format, as long as you give appropriate credit to the original author(s) and the source, provide a link to the Creative Commons license and indicate if changes were made.

The images or other third party material in this chapter are included in the chapter's Creative Commons license, unless indicated otherwise in a credit line to the material. If material is not included in the chapter's Creative Commons license and your intended use is not permitted by statutory regulation or exceeds the permitted use, you will need to obtain permission directly from the copyright holder.

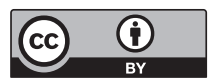

